\title{
Analisis Air Buangan Kantin di Kampus II Universitas Bhayangkara Jakarta Raya
}

\author{
Lisa Adhani ${ }^{1}$, Wahyu Kartika ${ }^{2}$,Dovina Navanti ${ }^{3}$ \\ ${ }^{1}$ Teknik Kimia, Fakultas Teknik Universitas Bhayangkara Jakarta Raya \\ ${ }^{2}$ Teknik Lingkungan, Fakultas Teknik Universitas Bhayangkara Jakarta Raya \\ Email: ${ }^{* 1}$ lisa.adhani@dsn.ubharajaya.ac.id, ${ }^{2}$ wahyukartika66@gmail.com, \\ 3.dovina_navanti@yahoo.com.
}

\begin{abstract}
Canteen is a producer of domestic liquid waste that has the potential to cause pollution. Likewise with the student canteen, it has the potential to produce waste that causes environmental pollution if it is not treated properly. The use of Montecarlo software in this study is to support quantitative analysis in predicting potential pollution from Ubhara canteen waste with Crystall ball prediction. The results of laboratory analysis in the form COD, BOD dan TSS, showed that the quality of the canteen waste water did not meet the requirements for wastewater quality standard based on Ministry of Environment Decree No. 112 of 2003. Supported by the results of $C B$ Predictor simulations showing the potential of pollution of the Ubhara canteen waste water to the environment continues to increase significantly, also seen from the Double Exponential Smoothing Method, producing MAD (Mean Absolute Deviation) 170.82, Theil's U 0.9951, and Confidence Interval Lower 5\% and Upper 99.5\%.
\end{abstract}

Keywords: Analysis, domestic waste, Montecarlo software, Crystall ball, Predictor

\section{PENDAHULUAN}

Air buangan merupakan limbah yang diperoleh dari kegiatan yang berhubungan dengan kehidupan sehari-hari. Jenis limbah cair ini dibedakan lagi atas sumber aktifitasnya, yaitu limbah cair yang berasal dari kegiatan industri dan limbah cair domestik yang berasal dari kegiatan rumah tangga. Sebelum limbah cair dikembalikan ke lingkungan, diperlukan tahapan pengolahan sampai mencapai baku mutu untuk mencegah terjadinya pencemaran lingkungan yang dapat membahayakan kehidupan manusia. Karakteristik yang bersifat spesifik dimiliki oleh limbah cair, akibatnya jenis pengolahan disesuaikan dengan karakteristik limbah cair tersebut.

Pencemaran dari limbah domestik di negara-negara berkembang merupakan penyebab terbesar pencemaran badan air(85\%), sedangkan di negara maju pencemar domestik mencakup $15 \%$ dari seluruh pencemar yang memasuki badan air[1]. Beberapa tahun terakhir ini, kualitas air sungai di Indonesia semakin mengalami penurunan terutama setelah melewati pemukiman, industri dan pertanian. Pencemaran air sungai terjadi akibat air limbah domestik penduduk dibuang langsung ke badan air tanpa melewati proses pengolahan terlebih dahulu, serta terbatasnya instalasi pengolahan limbah (IPAL) terpadu di kota besar maupun kota menengah dan kecil[2]. Limbah cair kantin berasal dari proses pencucian alat masak dan makan serta proses pengolahan makanan/minuman. Limbah ini dapat tergolong ke dalam limbah cair domestik. Bahan buangan yang biasanya terdapat dalam limbah kantin adalah bahan buangan organik dari olahan bahan makanan/minuman. Bahan buangan organik umumnya berupa limbah yang dapat membusuk atau terdegradasi oleh 
Lisa Adhani, Wahyu Kartika, Dovina Navanti

Submitted: 28 Oktober 2019; Revised:22 Desember 2019; Accepted: 6 Mret 2020; Published: 17 April 2020

mikroorganisme. Tidak menutup kemungkinan dengan bertambahnya mikroorganisme dapat berkembang pula bakteri pathogen yang berbahaya bagi manusia. Selain itu, buangan olahan bahan makanan adalah bahan buangan organik yang baunya lebih menyengat serta dapat menaikkan kadar BOD di perairan. Umumnya terkandung protein dan gugus amin pada buangan olahan makanan, maka jika didegradasi akan terurai menjadi senyawa yang mudah menguap dan berbau busuk[3]. Algoritme Monte Carlo merupakan metode Monte Carlo numerik yang dapat digunakan untuk menemukan solusi problem matematis (yang dapat terdiri dari banyak variabel) yang sulit dipecahkan, misalnya dengan kalkulus integral, atau metode numerik lainnya, Aplikasi metode Monte Carlo; Grafis, terutama untuk ray tracing; Permodelan transportasi ringan dalam jaringan multi lapis; bidang finansial;Simulasi prediksi; Pemetaan genetik yang melibatkan ratusan penanda genetik dan analisis QTL[4][5].

Simulasi Monte Carlo didefinisikan sebagai semua teknik sampling statistik yang dapat menganalisis solusi terhadap masalah kuantitatif untuk menghitung atau mengiterasi data-data sebuah penelitian dengan menggunakan nilai-nilai yang dipilih secara random dari distribusi probabilitas data yang mungkin terjadi dengan tujuan untuk mengukur dan

Tabel 1. Pendekatan dan Metode Penelitian Secara Umum menganalisis total dari sebuah penelitian dengan kearutan yang tinggi[4][6]

Air limbah kantin mahasiswa Universitas Bhayangkara Jakarta Raya (UBJ) adalah salah satu air buangan yang dapat menimbulkan pencemaran jika tidak diolah terlebih dahulu. Sumber pencemar yang terkandung di dalam air limbah kantin umumnya adalah minyak/lemak, deterjen, bakteri patogen, padatan organik dan anorganik. Berat jenis minyak/lemak yang lebih rendah daripada air apabila belum terolah secara baik, maka dapat menyebabkan penyumbatan pada pipa pembuangan. Selain itu kandungan minyak/lemak tersebut terbawa ke badan air permukaan maka akan menghalangi pertukaran oksigen dan penetrasi cahaya matahari yang dapat menyebabkan penurunan kualitas air[1].

\section{METODE PENELITIAN}

Jenis penelitian ini adalah penelitian laboratorium yang dilaksanakan dalam skala laboratorium. Pendekatan yang digunakan pada penelitian ini adalah pendekatan kualitatif yang memerlukan analisis kuantitatif[7]. Metode penelitian secara umum dijelaskan pada Tabel 1. berikut.

\begin{tabular}{llll}
\hline No. & Tujuan Penelitian & $\begin{array}{l}\text { Metode } \\
\text { Pengumpulan Data }\end{array}$ & $\begin{array}{l}\text { Metode } \\
\text { Analisis Data }\end{array}$ \\
\hline 1 & $\begin{array}{l}\text { Mengetahui jenis makanan dan } \\
\text { minuman yang terdapat pada kantin } \\
\text { mahasiswa }\end{array}$ & Analisis deskriptif \\
\hline 2 & $\begin{array}{l}\text { Mengetahui karakteristik limbah cair Uji Laboratorium } \\
\text { kantin mahasiswa ditinjau dari } \\
\text { parameter pH, BOD, COD, TSS, Total }\end{array}$ & $\begin{array}{l}\text { kalkulasi, analisis } \\
\text { kuantitatif }\end{array}$ \\
& $\begin{array}{l} \\
\text { Fosfat dan minyak/lemak. }\end{array}$ & \\
\hline 3 & $\begin{array}{l}\text { Menganalisis apakah air limbah kantin } \\
\text { mahasiswa sesuai Baku Mutu dokumen/peraturan } \\
\text { Kepmenlh No. 112 tahun 2003. }\end{array}$ & \\
&
\end{tabular}




\begin{tabular}{|c|c|c|c|}
\hline 4 & $\begin{array}{l}\text { Menganalisis apakah diperlukan } \\
\text { sistem pengolahan air limbah pada } \\
\text { kantin mahasiswa tersebut dan } \\
\text { seberapa penting untuk segera } \\
\text { diaplikasikan. }\end{array}$ & Analisis dokumen & $\begin{array}{lr}\text { Software } & \text { Montecarlo, } \\
\text { Kajian } & \text { literatur, } \\
\text { analisis deskriptif }\end{array}$ \\
\hline
\end{tabular}

2.1

Variabel Penelitian

a. Variabel Bebas : Debit air limbah kantin

b. Variabel Terikat :
Parameter yang diteliti
yaitu pH, BOD, COD,
TSS, Total Fosfat dan
Minyak/Lemak dari
effluent

\subsection{Objek Penelitian}

Objek penelitian adalah kandungan pH, BOD, COD, TSS, Total Fosfat dan Minyak/Lemak dari effluent kantin mahasiswa Ubhara Jaya.

\subsection{Lokasi Penelitian \\ Lokasi penelitian dilakukan di} kantin mahasiswa Univeristas Bhayangkara Jakarta Raya Kampus II Bekasi untuk pengambilan sampel air limbah dan laboratorium DLH Bekasi untuk pengujian parameter air limbah.

\subsection{Waktu Penelitian \\ Penelitian dilakukan selama} periode bulan Juni 2018 - Agustus 2018

\subsection{Pengambilan Sampel}

Air yang digunakan sebagai objek penelitian diambil dari air buangan kantin mahasiswa. Sampel air imbah diambil pada saat jam 09.00 dan 15.00 waktu ini dipilih karena pada jam 09.00 kantin UBJ mulai beraktivitas dan jam 15.00 adalah jam puncak mahasiswa makan siang di kantin UBJ.

\subsection{Teknik Pengumpulan Data \\ Pengumpulan data primer} dilakukan melalui uji laboratorium. Data primer yang diperoleh melalui uji laboratorium adalah hasil pengukuran kadar $\mathrm{pH}$, BOD, COD, TSS, Total Fosfat dan minyak/lemak.

Pengumpulan data sekunder adalah dengan melakukan analisis dokumen. Dokumen yang dimaksud antara lain buku, peraturan pemerintah/menteri, laporan penelitian.

\subsection{Diagram Alir Penelitian}

Perancangan penelitian dapat dilihat seperti pada gambar di bawah ini:

$$
\text { dapat dilihat seperti pada }
$$

gambar 1: 


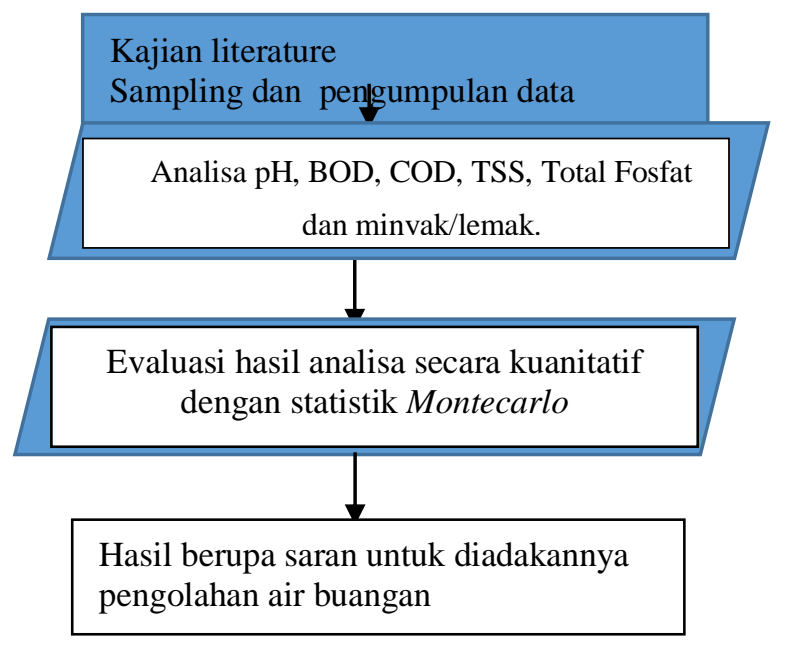

Gambar 1 Diagram Alir

\section{HASIL DAN PEMBAHASAN}

\subsection{Kantin UBJ}

Kantin Ubhara melayani seluruh civitas akademik terutama mahasiswa, bahkan dapat dikatakan menjadi pusat kegiatan mahasiswa, sehingga menjadi perhatian pada penelitian ini. Air limbah dan berbagai permasalahan terkait air limbah yang terjadi di kantin menjadi alasan mengapa kantin dipilih sebagai tempat penelitian, karena air limbah kantin langsung dibuang ke saluran drainase yang ada di lingkungan Ubhara. Fasilitas yang terdapat di Kantin antara lain kursi dan meja makan, 1 (satu) ruang makan dosen, 1 (satu) ruang pertemuan, 2(dua) wastafel untuk cuci tangan, dan 12 (dua belas) tempat cuci bahan dan piring. Sistem sanitasi di kantin ini juga masih belum dapat dikatakan memenuhi standar, seperti pembayaran yang langsung dipegang penjual yang juga melayani, sehingga hygiene penyajian makanan tidak terjaga sebab pedagang memegang uang yang tidak terjaga kebersihannya. Jumlah kursi dan meja di kantin hingga Agustus 2019 berjumlah 20 dapat menampung lebih dari 250 orang. Di dalam kantin terdapat 12 (dua belas) kios yang menjual makanan dan minuman. Oktober 2019 ini telah beroperasi pula kantin baru dan satu pojokan di lorong jalan yang dapat menampung konsumen juga sekitar 200 orang.

Jenis makanan dan minuman yang dijual antara lain, minuman ringan, aneka jus, makanan berat dan makanan ringan (snack). 


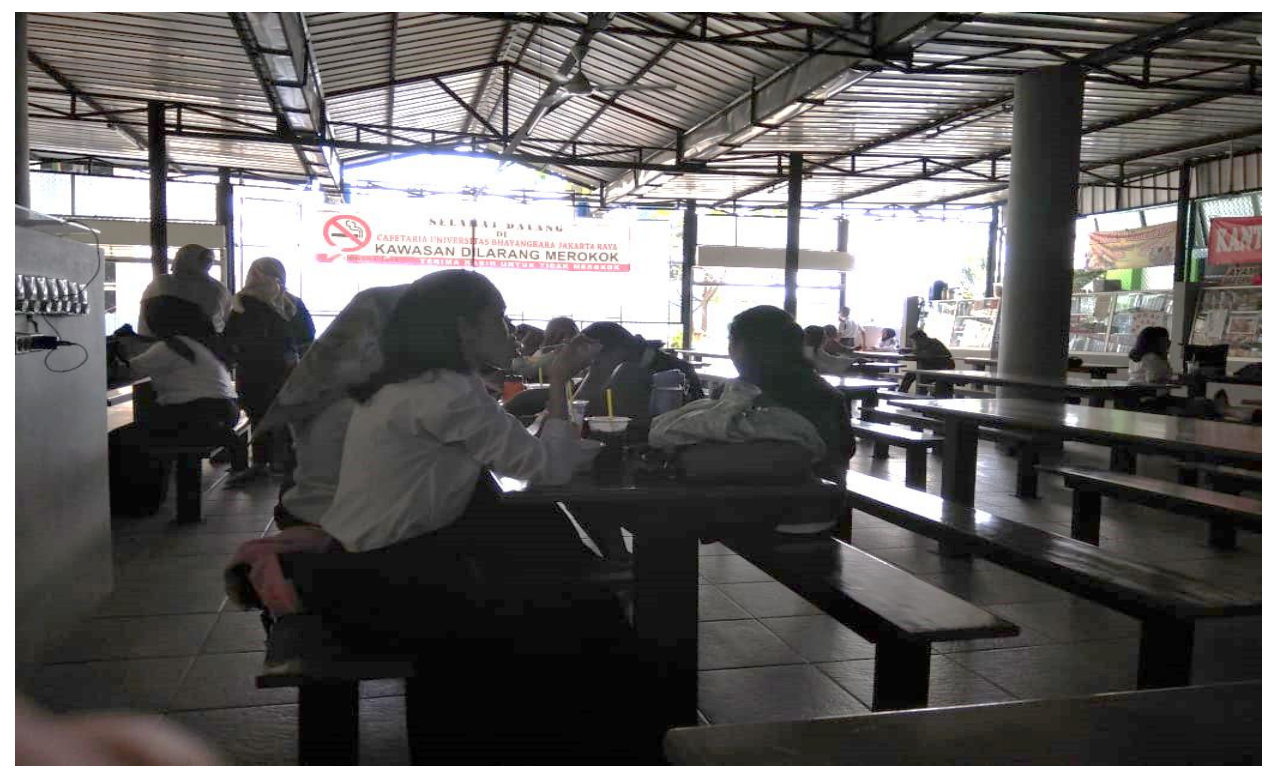

Gambar 2 Suasana kantin UBJ

Berdasarkan hasil pengamatan dan wawancara yang dilakukan pada para pedagang, diketahui bahwa waktu pencucian dilakukan saat pagi hari sekitar pukul 07.00 sampai dengan 9.00 untuk melakukan persiapan sebelum berjualan. Selajutnya dilakukan pukul 12.00 sampai dengan 15.00 untuk mencuci peralatan makan dan minum yang digunakan untuk penyajian saat makan siang, pukul 16.00-18.00 untuk makan malam. Terakhir adalah sekitar pukul 21 sampai 22.00 untuk membersihkan dan menutup kios. Volume limbah cair terbesar dihasilkan saat jam puncak, yaitu saat pencucian sisa makan siang antara pukul 12.00 sampai dengan 15.00 .

Jumlah bak cuci di kantin ini adalah sebanyak 12 buah. Satu bak cuci biasanya digunakan oleh 1 (satu) kios. Struktur bak cuci di kantin UBJ sama dengan bak cuci pada umumnya, bak cuci ini juga dilengkapi oleh saringan pada lubang pembuangan airnya untuk menyaring padatan yang terbawa bersama air limbah. Kantin UBJ belum memiliki unit pengolahan seperti unit penangkap lemak (grease trap), sumur resapan maupun sumur pengumpul sehingga air limbah bekas cucian langsung terbuang ke saluran limbah ke lingkungan.
Pengambilan sample awal dilakukan saat kantin UBJ memulai aktivitas di titik oulet dengan pengambilan sample pada pukul 09.00 WIB sebanyak 1.8 liter dengan media botol plastik. Pengambilan sample kedua dilakukan di titik oulet dengan pengambilan sample pada pukul 15.00 WIB sebanyak 1.8 liter dengan media botol plastik. Dapat dilihat pada air limbah kantin UBJ pada pengambilan sample kedua warna air limbah lebih keruh. Kekeruhan dinyatakan sebagai derajat kegelapan di dalam air yang dikarenakan oleh bahan-bahan melayang. Penetrasi cahaya matahari yang masuk ke badan perairan dipengaruhi oleh kekeruhan yang dapat menghalangi proses fotosintesis dan produksi primer perairan.

Air limbah kantin UBJ mengandung zat tersuspensi tinggi yang terdiri dari berbagai jenis senyawa seperti lemak, protein, selulosa yang melayanglayang dalam air atau dapat juga berupa mikroorganisme, seperti bakteri, algae, dan sebagainya. Pengurangan penetrasi matahari ke dalam badan air yang disebabkan oleh zat yang tersuspensi dapat memberikan dampak buruk terhadap kualitas air. Peningkatan kekeruhan air yang menjadi penyebab gangguan pertumbuhan bagi organisme produser[8].

\subsection{Debit Limbah Kantin UBJ}


Tabel 2 Data kualitas limbah kantin pada pembuangan Outlet pukul 09.00WIB

\begin{tabular}{lllcc}
\multicolumn{1}{c}{ PARAMETER } & SATUAN & HASIL UJ & BAKU MUTU & KETERANGAN \\
\hline Temperatur (lab) & ${ }^{\circ} \mathrm{C}$ & 28,4 & - & $\mathrm{M}$ \\
\hline $\begin{array}{l}\text { Padatan Tersuspensi } \\
\text { Total (TSS) }\end{array}$ & $\mathrm{mg} / \mathrm{L}$ & 40 & 30 & $\mathrm{TM}$ \\
\hline $\begin{array}{l}\text { Kebutuhan Oksigen } \\
\text { kimiawi (COD) }\end{array}$ & $\mathrm{mg} / \mathrm{L}$ & 286,51 & 100 & $\mathrm{TM}$ \\
\hline $\mathrm{pH}$ insitu & & 7,54 & $6,0-9,0$ & $\mathrm{M}$ \\
\hline $\begin{array}{l}\text { Daya Hantar listrik } \\
\text { (Lab) }\end{array}$ & $\mu \mathrm{S}$ & 559 & - & - \\
\hline $\begin{array}{c}\text { Kebutuhan Oksigen } \\
\text { Biologi (BOD) }\end{array}$ & $\mathrm{mg} / \mathrm{L}$ & 400 & 30 & $\mathrm{TM}$ \\
\hline
\end{tabular}

Tabel 3 Data kualitas limbah kantin pada pembuangan Outlet pukul 15.00WIB

\begin{tabular}{|c|c|c|c|c|}
\hline PARAMETER & SATUAN & HASIL UJI & BAKU MUTU & KETERANGAN \\
\hline Temperatur (lab) & ${ }^{\circ} \mathrm{C}$ & 28,3 & - & M \\
\hline $\begin{array}{l}\text { Padatan Tersuspensi } \\
\text { Total (TSS) } \\
\end{array}$ & $\mathrm{mg} / \mathrm{L}$ & 130 & 30 & TM \\
\hline $\begin{array}{l}\text { Kebutuhan Oksigen } \\
\text { kimiawi (COD) }\end{array}$ & $\mathrm{mg} / \mathrm{L}$ & 350,89 & 100 & TM \\
\hline $\mathrm{pH}$ insitu & - & 6,96 & $6,0-9,0$ & $\mathrm{M}$ \\
\hline $\begin{array}{l}\text { Daya Hantar listrik } \\
\text { (Lab) }\end{array}$ & $\mu S$ & 528 & - & - \\
\hline $\begin{array}{l}\text { Kebutuhan Oksigen } \\
\text { Biologi (BOD) }\end{array}$ & $\mathrm{mg} / \mathrm{L}$ & 190 & 30 & TM \\
\hline
\end{tabular}

Tabel 4 Data kualitas limbah kantin pada pembuangan Outlet pukul 15.00WIB

\begin{tabular}{|c|c|c|c|c|}
\hline PARAMETER & SATUAN & HASIL UJI & BAKU MUTU & KETERANGAN \\
\hline Temperatur (lab) & ${ }^{\circ} \mathrm{C}$ & 28,1 & - & $\mathrm{M}$ \\
\hline $\begin{array}{l}\text { Padatan Tersuspensi } \\
\text { Total (TSS) }\end{array}$ & $\mathrm{mg} / \mathrm{L}$ & 178 & 30 & TM \\
\hline $\begin{array}{l}\text { Kebutuhan Oksigen } \\
\text { kimiawi (COD) } \\
\end{array}$ & $\mathrm{mg} / \mathrm{L}$ & 1046,24 & 100 & TM \\
\hline $\mathrm{pH}$ insitu & - & 7,48 & $6,0-9,0$ & M \\
\hline $\begin{array}{l}\text { Daya Hantar listrik } \\
\text { (Lab) }\end{array}$ & $\mu S$ & 593,5 & - & - \\
\hline $\begin{array}{l}\text { Kebutuhan Oksigen } \\
\text { Biologi (BOD) }\end{array}$ & $\mathrm{mg} / \mathrm{L}$ & 30 & 30 & TM \\
\hline
\end{tabular}


3.3 Hasil Pengujian dan Pembahasan Konsentrasi Chemical Oksygen
Demand (COD)

Hasil pengujian laboratorium menunjukkan nilai COD air buangan kantin Ubhara di luar angka mutu yang dibolehkan untuk dibuang ke lingkungan yaitu pada titik outlet pukul 09.00 WIB sebesar 286,51 $\mathrm{mg} / \mathrm{L}$ dan pada pukul 15.00 sebesar 350,89 $\mathrm{mg} / \mathrm{L}$, sedangkan pada titik B pukul 15.00 sebesar 1046,24 mg/L. Hal ini menunjukkan bahwa nilai COD pada air buangan kan Ubhara Tidak Memenuhi Baku Mutu air limbah yang dapat dibuang ke lingkungan, dimana nilai COD pada baku mutu sebesar $100 \mathrm{mg} / \mathrm{L}$ [9].

COD adalah kebutuhan kadar oksigen untuk mengoksidasi zat-zat organik yang terdapat dalam limbah cair dengan memanfaatkan oksidator kalium dikromat sebagai sumber oksigen. COD merupakan ukuran bagi pencemaran air oleh zat organik yang secara alamiah dapat dioksidasi melalui proses biologis dan dapat menyebabkan berkurangnya oksigen terlarut dalam air. COD termasuk suatu uji yang dapat dipakai sebagai acuan jumlah organik di dalam air, dan pengujiannya lebih cepat dibanding BOD.

Nilai COD berhubungan dengan kadar oksigen terlarut, dan oksigen terlarut merupakan parameter penting karena dapat mengetahui gerakan massa air serta sebagai indikator bagi proses kimia dan biologi[10]. Nilai COD yang tinggi disebabkan oleh tingginya kandungan bahan organik yang berasal dari sisa makanan dan minuman, serta bahan anorganik yang berasal dari deterjen dan bahan kimia lainnya yang digunakan dalam proses pencucian. Jika air buangan dengan nilai COD yang tinggi akan menyebabkan berkurangnya oksigen dalam badan air sehingga mengurangi kemampuan badan air mengoksidasi bahan organik dan anorganik yang terkandung pada badan air sehingga menyebabkan pencemaran terhadap lingkungan[9].

3.4 Hasil Pengujian dan Pembahasan Konsentrasi Biological Oxygen Demand (BOD)
Nilai BOD air buangan kantin Ubhara pada titik outlet pukul 09.00WIB sebesar $400 \mathrm{mg} / \mathrm{L}$, pada pukul 15.00 WIB $190 \mathrm{mg} / \mathrm{L}$, dan pada titik outlet pukul 15.00 WIB sebesar $30 \mathrm{mg} / \mathrm{L}$. Sedangkan nilai baku mutu sebesar $30 \mathrm{mg} / \mathrm{L}$.

Limbah kantin umumnya mengandung bahan organik yang mudah terurai oleh bakteri. Bakteri aerob membutuhkan oksigen dalam proses penguraian atau dekomposisi bahan organik dalam air limbah. Menurut Effendi (2003), dekomposisi bahan organik dapat mengurangi kadar oksigen terlarut hingga mencapai nol (anaerob). Hal ini dapat menyebabkan bakteri pengurai aerob mati, sehingga proses degradasi bahan organik dalam air limbah akan terganggu.

$$
\text { Nilai BOD yang tinggi }
$$

menunjukkan berkurangnya oksigen yang dibutuhkan bakteri untuk mendekomposisi kandungan organik dalam badan air, ini merupakan satu parameter tercemarnya air buangan yang akan menyebabkan pencemaran terhadap lingkungan[9].

\subsection{Hasil Pengujian dan Pembahasan Konsentrasi Total Suspended Solid (TSS) \\ Hasil pengujian TSS air buangan} kantin Ubhara di titik outlet pada pukul 09.00 WIB sebesar 40/L, pada pukul 15.00WIB sebesar $130 \mathrm{mg} / \mathrm{L}$ dan di titik outlet pada pukul 15.00 WIB sebesar 178 $\mathrm{mg} / \mathrm{L}$. nilai TSS yang dihasilkan melebihi baku mutu yang disyaratkan yaitu sebesar $30 \mathrm{mg} / \mathrm{L}$.

Total Suspended Solid (TSS) atau total padatan tersuspensi adalah segala macam zat padat dari padatan total yang tertahan pada saringan dengan ukuran partikel maksimal 2,0 $\mu \mathrm{m}$ dan dapat mengendap[11]. Tingginya nilai TSS dalam suatu perairan dapat menghalangi penetrasi cahaya matahari sehingga menghambat proses fotosintesis yang terjadi di dalamnya. Selain itu, TSS juga dapat menyebabkan pendangkalan badan air sebab meningkatkan jumlah padatan yang terendap dalam badan air.

Sumber TSS ini sebagian besar berasal dari sisa makanan dan minuman 
selama proses pencucian. Selain itu saringan yang terdapat dalam bak cuci juga kurang memadai sehingga memungkinkan sisa padatan lolos dan terbawa dalam limbah cair kantin ditambah dari solid terlarut dari sabun/deterjen. Juga dari kegiatan menyiapkan makanan, dihasilkan sekitar 99\% larutan dan 0,1\% padatan. 99\% larutan yang terbentuk, 70\%nya berupa limbah organic dan 30\% berupa bahan anorganik menghasilkan garam, lumpur dan logam[12].

TSS akan menyebabkan masalah pada badan air seperti kekeruhan pada air buangan. Nilai kekeruhan yang tinggi dapat menghalangi penetrasi cahaya matahari yang menyebabkan terhambatnya proses fotosintesis terhambat dan menyebabkan eutrofikasi pada badan air. Oleh karena itu, diperlukan perbaikan pengolahan limbah cair kantin sebelum dibuang ke badan air sehingga tidak mencemari lingkungan[12].

\subsection{Hasil Pengujian dan Pembahasan $\mathrm{pH}$ \\ Pada hasil pengujian air buangan} kantin Ubhara $\mathrm{pH}$ di titik outlet pada pukul 09.00WIB 7,54, pada pukul 15.00WIB 6,96 menunjukkan semakin siang ada penurunan nilai $\mathrm{pH}$, hal ini dikarenakan bertambahnya nilai kandungan asam organik dan karbon dioksida $\left(\mathrm{CO}_{2}\right)$ yang dihasilkan dari dekomposisi bahan organik mikrorganisme difilm badan air menjadi asam karbonat. Sedang pada titik outlet $\mathrm{pH}$ menunjukkan

Summary:
$\begin{array}{r}\text { Crystal Ball Report - Predictor } \\ \text { Created } 8 / 31 / 2018 \text { at 10:10 PM }\end{array}$
$\begin{aligned} & \text { Data attributes: } \\ & \text { Number of series }\end{aligned}$
Data is in
$\begin{aligned} & \text { Run preferences: } \\ & \text { Periods to forecast }\end{aligned}$
$\begin{aligned} & \text { Fill-in missing values } \\ & \text { Adjust outliers }\end{aligned}$
Methods used
$\begin{aligned} & \text { On } \\ & \text { Forecasting technique }\end{aligned}$
Error measure

\section{Gambar 3 Crystall ball Report-Predictor}

Peramalan (forecasting) dilakukan dengan metode peramalan kuantitatif time series. Peramalan time series adalah metode kuantitatif untuk menganalisis data masa sebesar 7,48 menandakan masih adanya mikroorganisme pada badan air, dimana baku mutu air buangan untuk nilai $\mathrm{pH}$ adalah 6,0-9,0[13]. Nilai $\mathrm{pH}$ pada pengujian ini masih memenuhi syarat baku mutu, namun dilihat dari terjadinya penurunan $\mathrm{pH}$ di titik outlet pada pukul 09.00WIB dengan 15.00 WIB ada kemungkinan menurunnya $\mathrm{pH}$ air buangan karena hasil reaksi kandungan asam organik dan $\mathrm{CO}_{2}$ hasil dekomposisi mikroorganisme. Kecenderungan penurunan $\mathrm{pH}$ ini akan menghambat pertumbuhan bakteri pengurai karena banyaknya asam-asam mineral dan organik yang akan menyebabkan terjadinya pencemaran[13].

\subsection{Crystal Ball Prediction}

Analisis yang dilakukan satu kali sampling dalam satu hari sesuai dengan kemampuan biaya analisis, maka dilakukan prediksi hasil analisis untuk 18 hari ke depan dengan sampling pada nilai COD yang dapat mewakili nilai hasil pengujian lainnya dikarenakan nilai COD merupakan nilai total kandungan organik dan non organik dalam badan air buangan kantin. Prediksi dilakukan dengan simulasi Crystall Ball Prediction menggunakan software montecarlo[14]. Simulasi yang dilakukan sebagai berikut:

lalu yang telah dikumpulkan secara teratur menggunakan teknik yang tepat. Hasilnya dapat dijadikan acuan untuk peramalan nilai di masa yang akan datang[15]. Dengan metode peramalan yang disimulasi adalah 
metode umum untuk peramalan time series. Hasil yang didapat dapat dilihat pada Tabel 5.

Software Montercarlo merupakan perangkat yang sangat user friendly, sehingga memberi kemudahan mengeksplorasi dan menguji seluruh peramalan yang dapat dilakukan dalam simulasi Crystall Ball Predictor. Dari sebelas metode yang diuji di dapatkan bahwa metode Double Exponential Smoothing lebih tepat, dilihat dari nilai Thell's $U$ sebesar 0,9951 yang menyatakan model ramalan lebih baik dibandingkan pendugaan. Juga dilihat dari MAD (Mean Absolute Deviation) yang merupakan metode peramalan untuk mengevaluasi dengan menggunakan jumlah dari kesalahan-kesalahan yang absolut. MAD mengukur ketepatan ramalan dengan merata-rata kesalahan dugaan (nilai absolut masing-masing kesalahan) yang berguna mengukur kesalahan ramalan dalam unit yang sama sebagai deret asli. Nilai MAD dapat dihitung dengan menggunakan rumus sebagai berikut.

$M A D=\frac{\sum(\text { Absolut dari forecast errors })}{n}$

Tabel 5 Peramalan Time Series Montecarlo Predictor dengan 11 metode

\begin{tabular}{|c|c|c|c|c|c|c|c|c|c|c|c|}
\hline Methods & Rank & MAD & RMSE & MAPE & Theil's U & Durbin-W & Alpha & Beta & Gamma & Order & Phi \\
\hline Damped Trend Non-Seasonal & 2 & 170,84 & 313,90 & $31,44 \%$ & 0,9951 & 1,927 & 0,4890 & 0,9990 & & & 0,9988 \\
\hline Damped Trend Seasonal Additive & 7 & 229,67 & 362,54 & $32,83 \%$ & 0,8997 & 1,7855 & 0,9990 & 0,2258 & 0,6022 & & 0,4412 \\
\hline Damped Trend Seasonal Multiplicative & 5 & 217,08 & 340,86 & $30,75 \%$ & 0,8462 & 1,7713 & 0,9939 & 0,7956 & 0,0818 & & 0,4830 \\
\hline Double Exponential Smoothing & 1 & 170,82 & 313,88 & $31,44 \%$ & 0,9951 & 1,9272 & 0,4887 & 0,9990 & & & \\
\hline Double Moving Average & 11 & 327,28 & 439,58 & $45,15 \%$ & 1,0466 & 2,3899 & & & & 2 & \\
\hline Holt-Winters' Additive & 8 & 229,78 & 362,73 & $32,85 \%$ & 0,9001 & 1,7856 & 0,9990 & 0,0944 & 0,7479 & & \\
\hline Holt-Winters' Multiplicative & 6 & 217,71 & 341,94 & $30,85 \%$ & 0,8488 & 1,7721 & 0,9990 & 0,3534 & 0,1014 & & \\
\hline Seasonal Additive & 9 & 253,48 & 368,14 & $36,86 \%$ & 0,9093 & 1,5778 & 0,9990 & & 0,0010 & & \\
\hline Seasonal Multiplicative & 10 & 291,14 & 374,77 & $43,53 \%$ & 0,893 & 1,1506 & 0,9990 & & 0,7753 & & \\
\hline Single Exponential Smoothing & 4 & 177,82 & 314,97 & $32,92 \%$ & 1,0001 & 1,8427 & 0,9990 & & & & \\
\hline Single Moving Average & 3 & 177,70 & 314,94 & $32,90 \%$ & 1,00 & 1,8445 & & & & 1 & \\
\hline
\end{tabular}

Historical data:

$\begin{array}{lc}\text { Statistic } & \text { Historical data } \\ \text { Data Values } & 6 \\ \text { Minimum } & 286.51 \\ \text { Mean } & 561,21 \\ \text { Maximum } & 1.046 .24 \\ \text { Standard Deviation } & 376,80 \\ \text { Ljung-Box } & 3.85 \text { (Detrended) } \\ \text { Seasonality } & 3 \text { (Manually set) } \\ \text { Screened Values } & 0\end{array}$

Gambar 4 Historical data 
Lisa Adhani, Wahyu Kartika, Dovina Navanti

Submitted: 28 Oktober 2019; Revised:22 Desember 2019; Accepted: 6 Mret 2020; Published: 17 April 2020

Predictor Series

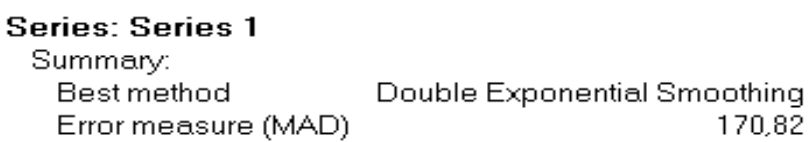

Series: Series 1

Summary:

Best method Double Exponential Smoothing

Error measure (MAD)

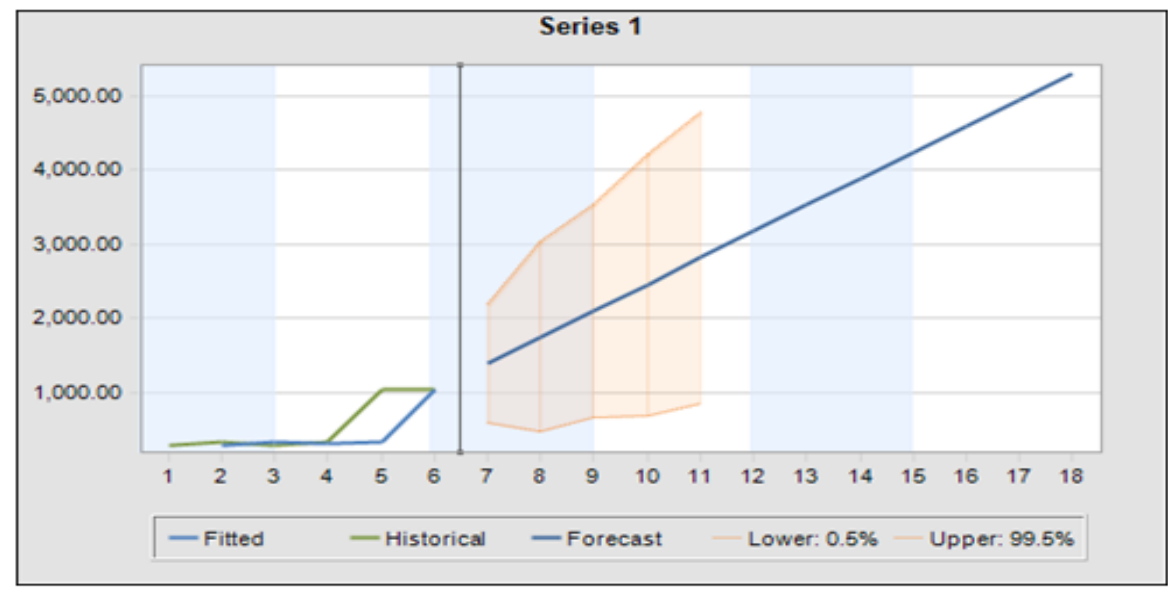

Gambar 5 Predictor Series (simulasi prediksi dengan Crystall Ball)

Forecast accuracy:

$\begin{array}{lrr}\text { Method } & \text { Rank } & \text { MAD } \\ \text { Double Exponential Smoothing } & \text { Best } & \mathbf{1 7 0 , 8 2} \\ \text { Damped Trend Non-Seasonal } & \text { 2nd } & 170,84 \\ \text { Single Moving Average } & \text { 3rd } & 177.70\end{array}$

\begin{tabular}{lrr} 
Method & Theil's U & Durbin-Watson \\
\hline Double Exponential Smoothing & 0,9951 & 1.93 \\
Damped Trend Non-Seasonal & 0,9951 & 1.93 \\
Single Moving Average & 1,00 & 1.84 \\
\hline
\end{tabular}

Method parameters:

\begin{tabular}{lrr} 
Method & Parameter & Value \\
\hline Double Exponential Smoothing & Alpha & 0.4887 \\
& Beta & 0.9990 \\
Damped Trend Non-Seasonal & Alpha & 0.4890 \\
& Beta & 0.9990 \\
Single Moving Average & Phi & 0.9988 \\
& Order & 1
\end{tabular}

Gambar 6 Forecast accuracy 


\section{Forecast results:}

\begin{tabular}{|c|c|c|c|}
\hline Period & Lower: $0.5 \%$ & Forecast & Upper: $99.5 \%$ \\
\hline 7 & 593,29 & 1.401 .80 & $2.210,30$ \\
\hline 8 & 476.21 & 1.75735 & 3.03850 \\
\hline 9 & 677,00 & $2.112,91$ & $3.548,82$ \\
\hline 10 & 702,32 & 2.468 .47 & $4.234,61$ \\
\hline 11 & 867,09 & $2.824,03$ & $4.780,96$ \\
\hline 12 & - & $3.179,58$ & - \\
\hline 13 & - & $3.535,14$ & - \\
\hline 14 & - & $3.890,70$ & - \\
\hline 15 & - & $4.246,26$ & - \\
\hline 16 & - & 4.601 .81 & - \\
\hline 17 & - & $4.957,37$ & - \\
\hline 18 & - & $5.312,93$ & - \\
\hline
\end{tabular}

\section{Gambar 7 Forecast Results}

Dari Gambar 5, Gambar 6 dan Gambar 7, tampak jelas bahwa COD sebagai parameter pencemaran, semakin hari semakin meningkat, dengan Confident Interval Lower 5\% dan Upper 99,5\%. Sehingga sangat diperlukan pengolahan air buangan kantin Ubhara sebelum dibuang ke lingkungan.

\section{KESIMPULAN DAN SARAN}

Hasil penelitian menunjukkan Air buangan Kantin UBJ mengandung kadar polutan yang belum memenuhi baku mutu yang disyaratkan, yaitu Kepmen LH No. 112 tahun 2003 untuk parameter BOD, COD, TSS.

Nilai COD air buangan kantin UBJ sebesar 1046,24 mg/L, nilai BOD sebesar $190 \mathrm{mg} / \mathrm{L}$, dan nilai TSS sebesar $178 \mathrm{mg} / \mathrm{L}$. Hal ini menunjukkan bahwa nilai COD pada air buangan kantin Ubhara tidak memenuhi Baku Mutu air limbah yang dapat dibuang ke lingkungan, dimana nilai COD pada baku mutu sebesar $100 \mathrm{mg} / \mathrm{L}$, sedangkan nilai baku mutu BOD sebesar 30 $\mathrm{mg} / \mathrm{L}$ dan nilai baku mutu TSS yaitu sebesar $30 \mathrm{mg} / \mathrm{L}$. Nilai COD, BOD dan TSS pada air buangan kantin Ubhara yang tinggi akan menyebabkan berkurangnya oksigen dalam badan air sehingga mengurangi kemampuan badan air mengoksidasi bahan organik dan anorganik yang terkandung pada badan air sehingga menyebabkan pencemaran terhadap lingkungan.

Limbah cair kantin berpotensi besar sebagai pencemar lingkungan jika tidak segera dilakukan pengolahan limbah di lihat dari hasil $C B$ Predictor dengan 12 forecast menunjukkan tingkat pencemaran yang terus naik secara signifikan, Metode yang terpilih adalah Double Exponensial Smoothing, dengan MAD (Mean Absolute Deviation) 170,82, Theil's U 0,9951, dan tingkat kepercayaan (Confident Interval) terhadap hasil prediksi adalah; Lower 5\% dan Upper $99,5 \%$.

Saran pada penelitian ini adalah perlu segera dilakukan pengolahan air buangan kantin, dilihat dari hasil simulasi Crystall Ball Predictor dengan menggunakan data hasil pengujian laboratorium COD, bahwa kemungkinan meningkatnya nilai COD sangatlah eksponensial mengingat kantin beroperasi 6 hari dalam seminggu dan jumlah mahasiswa yang semakin meningkat, sehingga limbah cair kantin Ubhara sangat berpotensi sebagai pencemar lingkungan

\section{UCAPAN TERIMA KASIH}

Kami ucapkan terimakasih kepada LPPM Universitas Bhayangkara Jakarta raya yang telah membiayai penelitian ini 


\section{DAFTAR PUSTAKA}

[1] U. Suriawiria, Mikrobiologi Air dan Dasar-dasar Pengolahan Buangan Secara Biologis. 2016.

[2] A. F. Widiyanto, S. Yuniarno, and K. Kuswanto, "POLUSI AIR TANAH AKIBAT LIMBAH INDUSTRI DAN LIMBAH RUMAH TANGGA," J. Kesehat. Masy., 2015.

[3] L. Warlina, "Pencemaran air : sumber, dampak dan penanggulangannya," Makal. pribadi, 2004.

[4] X. Tian and K. Benkrid, "Highperformance Quasi-Monte Carlo financial simulation: FPGA vs. GPP vs. GPU," ACM Trans.

Reconfigurable Technol. Syst., 2010.

[5] A. Muniesa, C. Ferreira, H. Fuertes, N. Halaihel, and I. De Blas, "Estimation of the relative sensitivity of qPCR analysis using pooled samples," PLoS One, 2014. "EL MÉTODO DE SIMULACIÓN DE MONTECARLO EN ESTUDIOS DE CONFIABILIDAD DE SISTEMAS DE DISTRIBUCIÓN DE ENERGÍA ELÉCTRICA,”Sci. Tech., 2004.

[7] A. Purba Asmara Program Studi Kimia, F. Sains dan Teknologi, U. Ar Raniry Banda Aceh, arraniryacid Mudasir, D. Siswanta Jurusan Kimia, and F. Matematika dan Ilmu Pengetahuan Alam, "Penentuan Metode Komputasi Untuk Analisis Hubungan Kuantitatif Struktur Dan Aktivitas Senyawa Turunan Triazolopiperazin Amida," J. Islam. Sci. Technol., 2015.

[8] B. Hamuna, R. H. R. Tanjung, S. Suwito, H. K. Maury, and A. Alianto, "Kajian Kualitas Air Laut dan Indeks Pencemaran Berdasarkan Parameter Fisika-Kimia di Perairan Distrik Depapre, Jayapura," J. Ilmu Lingkung., 2018.

[9] R. B. and A. Mallongi, "Studi Karakteristik Dan Kualitas BOD
Dan COD Limbah Cair Rumah Sakit Umum Daerah Lanto DG. Pasewang Kabupaten Jeneponto," $J$. Nas. Ilmu Kesehat., 2018.

[10] L. Nurajijah, D. Harjunowibowo, and Y. Radiyono, "Pengaruh Variasi Tegangan pada Pengolahan Limbah Cair Laundry Menggunakan Proses Elektrolisis," J. Mater. dan Pembelajaran Fis., 2014.

[11] M. H. Jusof Khadidi and E. A. Hamid, "A New FlocculantCoagulant with Potential Use for Industrial Wastewater Treatment," 2nd Int. Conf. Environ. Energy Biotechnol., 2013.

[12] L. Rossi, V. Krejci, W. Rauch, S. Kreikenbaum, R. Fankhauser, and W. Gujer, "Stochastic modeling of total suspended solids (TSS) in urban areas during rain events," Water Res., 2005.

[13] T. Susana, "TINGKAT KEASAMAN (pH) DAN OKSIGEN TERLARUT SEBAGAI INDIKATOR KUALITAS PERAIRAN SEKITAR MUARA SUNGAI CISADANE," Indones. $J$. URBAN Environ. Technol., 2009.

[14] S. Sandrone, "The Brain as a Crystal Ball: The Predictive Potential of Default Mode Network," Front. Hum. Neurosci., 2012.

[15] C. Kaufman-Scarborough, M. Morrin, and E. T. Bradlow, "Improving the crystal ball: Harnessing consumer input to create retail prediction markets," J. Res. Interact. Mark., 2010. 